\title{
Effect of Curcumin versus Hyaluronic Acid on Glucocorticoid Induced Skin Atrophy and Subsequent Skin Abrasions in Rats
}

\author{
Original \\ Article
}

\author{
Sohair Ahmed Fawzy, Nagwa Abd Elwahab Ahmed, Mohamed Deiaa Eldin \\ Elshafie, Samia Hamdy Radwan
}

Histology Department, Faculty of Medicine, Cairo University, Cairo, Egypt

\begin{abstract}
Background: Skin is the largest organ of the body in surface area and weight. One of the most important side effects of topical glucocorticoids therapy is skin atrophy. This study aimed to evaluate the possible therapeutic effects of curcumin versus aftamed gel (Hyaluronic Acid) on glucocorticoid-induced skin atrophy, as well as on subsequently induced abrasion wounds.

Methods: Forty two adult male albino rats were divided into 4 groups: Group1 (Control group) of 6 rats, Group II (SteroidExposed Group), Group III (Curcumin-Treated Group) and Group IV (Aftamed-treated group). Each of group II, III and IV were subdivided into two subgroups IIA, IIIA, IVA (subjected to clobetasol propionate cream) each included 6 rats and IIB, IIIB, IVB (subjected to clobetasol propionate cream, then exposed to skin abrasion) each included 6 rats. Skin biopsies were taken from the dorsum of rats 12th days from the stoppage of clobetasol propionate application. Sections were stained with hematoxylin and eosin, Masson's trichrome and immunohistochemichal stain for PCNA \& CK19. Epidermal thicknesses, mean area percent of collagen fibers and mean number of PCNA \& CK19 immunopositive cells were measured.

Results: Steroid-exposed group showed thinning of epidermal and dermal layers with scanty hair follicles and sebaceous glands as well as delay in wound healing. Increased epidermal thickness and reorganized dermal structural elements with increased PCNA \& CK19 immunopositive cells were more obvious in curcumin treated group than aftamed treated group. Conclusion: topical application of curcumin had more improving effect on skin and its abrasions rather than aftamed gel.
\end{abstract}

Received: 10 November 2018, Accepted: 12 November 2018

Key Words: Curcumin, hyaluronic acid, skin atrophy, topical steroids, wound.

Corresponding Author: Samia Hamdy Radwan, M.D., Histology Department, Faculty of Medicine, Cairo University, Egypt, Tel.: +20 1227172848, E-mail: samiahamdy@yahoo.com

ISSN: 1110-0559, Vol. 42, No. 1

\section{INTRODUCTION}

Topical glucocorticoids (GCs) were introduced into dermatological therapy in 1952 , when ${ }^{[1]}$ successfully used topical hydrocortisone to treat skin diseases. Due to their potent anti-inflammatory and anti-proliferative actions, GCs are currently an important class of drugs in dermatologic therapeutic field ${ }^{[2]}$. However, the same molecular mechanisms responsible for the treatment of inflammatory dermatological diseases also frequently induce adverse secondary conditions of which skin atrophy is the most important side effect ${ }^{[3]}$. Also they seem to delay the wound healing process ${ }^{[4]}$. In animals, it was reported that corticosteroids reduce the inflammatory phase of wound healing ${ }^{[5]}$.

Aftamed is a new formulation of high molecular weight hyaluronic acid demonstrated by controlled clinical trials. It promotes healing of ulcers and reduces their numbers by controlling inflammatory processes and dehydrating the tissues $^{[6]}$.

Therapeutic benefits of dietary constituents of plant origin have been the focus of many extensive studies ${ }^{[7]}$.
Curcumin is the active component of an Indian spice called turmeric, extracted from the rhizomes of Curcuma longa. Several studies have substantiated and provided scientific evidence regarding the potential prophylactic or therapeutic use of curcumin unraveling anti-inflammatory, anti-carcinogenic, anti-infectious, cell proliferation, anti-apoptotic and wound healing activities of this compound ${ }^{[8 \& 9]}$.

The purpose of present study was to evaluate possible therapeutic effects of curcumin versus aftamed gel on glucocorticoid-induced skin atrophy, as well as on the subsequently induced abrasion wounds with a trial to elucidate the possible underlying mechanisms. Histological, immunohistochemical and morphometric studies were used in this work.

\section{MATERIALS AND METHODS}

\section{Drugs:}

- Clobetasol propionate: A corticosteroid of glucocorticoid class was obtained from GlaxoSmithKline (SAE, Egypt), in the form of Dermovate cream 25g. 
- Curcumin: Obtained from Arab Company for Pharmaceuticals and Medicinal plants MEPACOEgypt. It was prepared in form of ethanol dissolved powder.

- Aftamed gel: A high-molecular-weight hyaluronic acid $240 \mathrm{mg} / 100 \mathrm{~g}$ gel. It was obtained from Bioplaxpharma (London, UK).

\section{Animals:}

In this study, 42 adult male albino rats weighting $180-200$ gm were bred in Animal House of Faculty of Medicine, Cairo University. Rats were housed in metal cages, in normal light-dark cycle at room temperature and were fed normal rat diet and water ad libitum. All experimental protocols were following guidelines for animal research approved by Animal Ethics Committee, Faculty of medicine, Cairo University.

- Induction of Skin Atrophy: Hair of dorsum of all experimental rats was shaved at the same time using a standard hair shaver. Clobetasol propionate was applied in form of $0.05 \%$ cream at a dosage of $0.25 \mathrm{~g} / \mathrm{kg}$ once a day for 15 successive days ${ }^{[10]}$.

- Induction of skin abrasion wound: Skin abrasion was performed after fifteen days from the beginning of the experiment. Under general anesthesia with an intraperitoneal injection of ketamine at a dose of $100 \mathrm{mg} /$ $\mathrm{kg}$ body weight, skin of rat dorsum was cleaned using ethanol at concentration of $70 \%$, then was abraded with a piece of course sanding sponge ${ }^{[11 \& 12]}$. Abrasion was sufficient to remove the epidermis and superficial part of dermis. Oozing of fluid (with a small amount of blood) into the abraded area indicated that appropriate degree of abrasion had been achieved. Injury was designed to approximate abrasion that commonly occur after a minor scrape $^{[12]}$ (Fig.1).

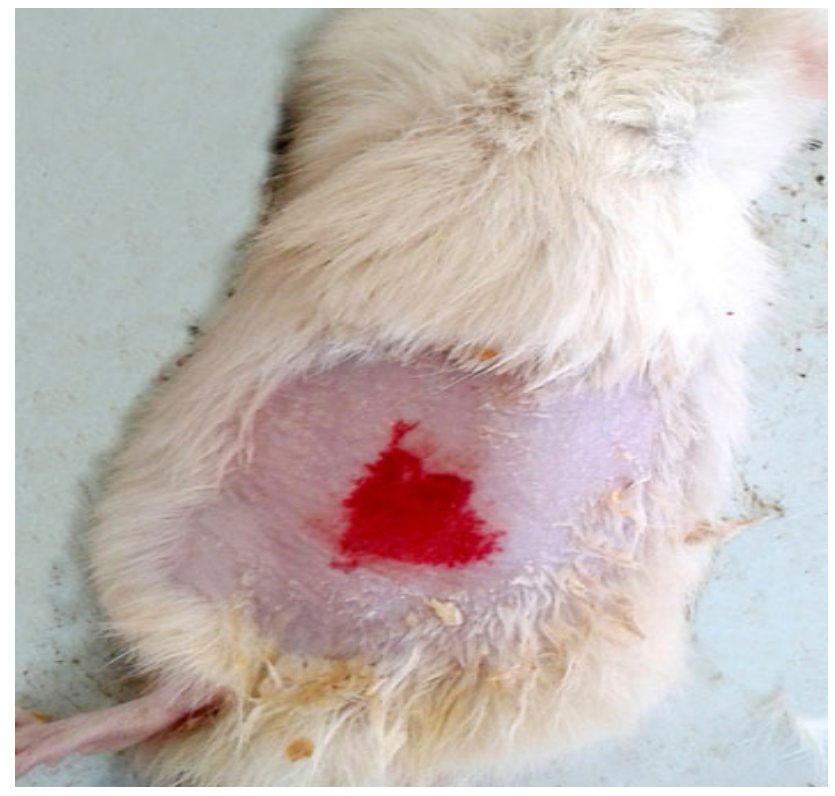

Fig. 1: A photomicrograph showing skin wound creation.

\section{- Experimental design:}

The animals were divided into the following groups:

Group I (Control group): six rats were equally subdivided into:

- Subgroup IA: rats received distilled water once daily for 15 days topically on skin, then one of them were exposed to skin abrasion. Rats were lifted for another twelve days before sacrificed.

- Subgroup IB: rats received distilled water once daily for 15 days topically on the skin, then one of them were exposed to skin abrasion. Following that, rats were received topical application of ethanol in a dose of $0.2 \mathrm{ml} /$ rat once daily for twelve days before sacrificed.

- Subgroup IC: rats received distilled water once daily for 15 days topically on skin, then one of them were undergo skin abrasion. Following that, rats were continued to receive distilled water for another twelve days.

Group II (Steroid-Exposed Group): 12 rats were equally subdivided into:

- Subgroup IIA: subjected to clobetasol propionate $0.05 \%$ cream topically in a dose of $(0.25 \mathrm{~g} / \mathrm{kg})$ once daily for 15 days $^{[10]}$. Then this group were lifted untreated for 12 days, then were sacrificed.

- Subgroup IIB: subjected to clobetasol propionate in the same way as in subgroup IIA, after 15 days they were exposed to skin abrasion. Then, rats were lifted untreated for 12 days, then were sacrificed.

Group III (Curcumin-Treated Group): 12 rats were equally subdivided into:

- Subgroup IIIA: subjected to clobetasol propionate application in the same way as in subgroup IIA. Then, they received curcumin topically in a dose of $0.2 \mathrm{ml}$ at a concentration of $100 \mathrm{mg} / \mathrm{kg}$ body weight once daily for a period of twelve days ${ }^{[13]}$. Then they were sacrificed.

- Subgroup IIIB: subjected to clobetasol propionate application and skin abrasion as in subgroup IIB. Then they received curcumin topically for twelve days as in group IIIA. Then they were sacrificed.

Group IV (Aftamed-treated group): 12 rats were subdivided equally into:

- Subgroup IVA: subjected to clobetasol propionate application in the same way as in subgroup IIA. Then received aftamed gel topically in a dose of $0.2 \mathrm{ml}$ twice daily for 12 days $^{[14]}$ before they were sacrificed.

- Subgroup IVB: subjected to clobetasol propionate application and skin abrasion as in subgroup IIB. Then they received aftamed gel topically for 
12 days as in subgroup IVA before they were sacrificed.

Under anesthesia by intraperitoneal injection of pentobarbitone sodium $60 \mathrm{mg} / \mathrm{kg}^{[15]}$, rats were sacrificed at the twelfth day from stoppage of clobetasol propionate application. Skin specimens were obtained from rat dorsum (fixed area for all rats) and were fixed in $10 \%$ buffered formalin solution for 24 hours, dehydrated in ascending grades of ethanol concentration, cleaned in xylol and embedded in paraffin. Serial skin sections of 5-7 micrometer thickness were cut and then mounted on glass slides. For immunohistochemical studies, sections were mounted on positive charged glass slides. Specimens were subjected to the followings:

a) $H$ \& E stain to examine morphological changes ${ }^{[16]}$.

b) Masson's Trichrome stain to demonstrate collagen fibers content of connective tissue dermis ${ }^{[17]}$.

c) Immunohistochemical staining ${ }^{[18]}$ for:

- PCNA: A marker for cell proliferation.

- CK19: A marker for hair follicle bulge stem cells.

\section{Morphometric Studies:}

Data were obtained using "Leica Qwin $500 \mathrm{C}$ " image analyzer computer system Ltd. (Cambridge, England). All measurements were detected in 10 randomly chosen non overlapping fields for each section. The following parameters were measured:

1. Epidermal thickness.

2. Mean area $\%$ of collagen fibers in the dermis.

3. Mean number of PCNA immunostained positive cells.

4. Mean number of CK19 immunostained positive cells.

\section{Statistical Analysis:}

Data were tabulated and statistically analyzed to evaluate the difference between groups under study as regards the various parameters. Mean, standard deviation and analysis of variance (ANOVA) were calculated using EXCEL and SPSS 9.0 Software. Results were considered statistically significant when $\mathrm{p}$ was $<0.05$.

\section{RESULTS}

Gross, histological and immunohistochemical results of all subgroups of control group (group I) were similar. So, they were referred to by control group.

\section{Gross evaluation of skin (Plate. 1):}

During experiment, animals appeared healthy as it is evidenced by normal appetite and behavior. All rats showed no sign of infections or mortality throughout the experimental period.

Control group exhibited apparently healthy and thick skin. Subgroup IIA showed atrophic changes in the form of thinning and wrinkling of skin. Rats of subgroups IIIA \& IVA showed healthy thick appearance of their skin as compared to subgroup IIA. By the end of experiment, wound area in subgroup IIB was completely covered by a scab. Meanwhile wounds in subgroups IIIB \& IVB were completely closed in all rats with complete restoring of normal skin appearance.

\section{Histological Results:}

\section{Haematoxylin and Eosin Stained Skin Sections:}

Histological examination of rat skin sections in control group revealed normal skin. Epidermis was formed of many cell layers (basal, prickle, granular cell layers and horny layer) with Langerhans cells were seen in intermediate layer. Dermis was consisted of densely packed, variably oriented, thick bundles of collagen fibers with many fibroblasts in-between. Many hair follicles and associated sebaceous glands were evident in dermis (Plate. 2).

Subgroup IIA revealed thinning of epidermis with reduced size and number of keratinocytes as well as increased spaces in-between their nuclei. Scanty hair follicles and sebaceous glands were also observed. Dermis showed few fibroblasts with separation of collagen bundles. Subgroup IIIA showed increased epidermal thickness with many hair follicles and sebaceous glands as compared with subgroup IIA, meanwhile subgroup IVA exhibited thin epidermis with few hair follicles and sebaceous glands. But both subgroups showed an increase in dermal cellularity with denser arrangement of its collagen bundles (Plate. 2). In subgroup IIB, wound surface was covered by crust formed of organized fibrin and inflammatory cell infiltrate. Wound bed was filled with massive inflammatory cell infiltrate as well as numerous dilated congested blood (granulation tissue) with absence of epidermal cells and skin appendages. Epidermis adjacent to wound edge was thickened and showed numerous Langerhans cells. Subgroup IIIB demonstrated wound area with complete regeneration of epidermal and dermal layers apart of small area of granulation tissue (mild inflammatory cell infiltration and few dilated blood vessels) in upper part of dermis as well as well recovered skin appendages including hair follicles and sebaceous glands. In subgroup IVB, wound surface was covered by apparently thick epidermis and wound bed was filled by regenerated dermal components with wide area of granulation tissue and few skin appendages (Plate. 3 ).

\section{Masson's Trichrome stained skin sections (Plate. 4):}

By MT stain in control group, dermis appeared formed of papillary and reticular layers. Papillary layer was consisted of loose connective tissue (CT) with narrow separated collagen bundle, while the underlying reticular layer was composed of dense irregular white fibrous CT with coarse collagen bundles. In subgroup IIA, dermis was formed of widely separated thin collagen bundles as compared to those of control group. Subgroups IIIA \& 
IVA had apparently normal histological architecture of dermis apart of slight narrowing of papillary layer noticed in subgroup IVA. Wound bed in subgroup IIB showed prominent deposition of light blue thin collagen fibers in granulation tissue, mostly arranged in horizontal direction. While thicker blue collagen bundles arranged in different directions were present at wound edge. On other hand, wound area in subgroups IIIB \& IVB showed prominent deposition of thin collagen bundles at upper part of regenerated dermis while deep part was filled with dense thick collagen bundles arranged in different directions in a network like manner.

\section{Immunostaining with PCNA (Plate. 5):}

Skin sections from control group revealed widespread moderate to dense nuclear immunoreactivity at cells of stratum basale, some cells of stratum spinosum, cells of outer root sheath (ORS) of hair follicles as well as in fibroblast cells interspersed in between collagen bundles of dermis while subgroup IIA showed weak localized immunoreactivity in few cells of stratum basale and in few cells of ORS of hair follicles. Subgroups IIIA \& IVA exhibited dense immunoreactivity in cells of stratum basale, some cells of stratum spinosum as well as in fibroblasts, moreover in subgroup IIIA, dense immunoreactivity was observed at cells of ORS. In subgroup IIB, widespread dense immunoreactivity was detected in cells of strata basale and spinosum at wound margin as well as widespread immunoreactivity in mononuclear cells, fibroblasts and endothelium of blood vessels within regenerated granulation tissue. Subgroups IIIB \& IVB showed dense immunoreactivity at cells of stratum basale, some cells of stratum spinosum, mononuclear cells and fibroblasts. Moreover immunoreactivity was seen in ORS and basal cells of sebaceous glands in subgroup IIIB.

\section{Immunostaining with CK19 (Plate. 6):}

Examination of skin sections from control group, subgroups IIIA, IIIB and IVA showed positive cytoplasmic immunoreactivity at cells of ORS of hair follicles meanwhile subgroup IIA showed weak immunoreactivity in few cells of ORS. On other hand subgroup IIB showed cytoplasmic immunoreactivity in epidermal cells of wound margin, some cells with CK19 immunoreaction scattered at wound bed were also seen. Subgroup IVB revealed positive immunoreactivity at some cells of regenerated epithelium.

\section{Morphometric Results:}

\section{Epidermal Thickness (Histogram 1):}

Mean epidermal thickness was $57.3 \pm 18.0 \mu \mathrm{m}, 12.2 \pm 2.9$ $\mu \mathrm{m}, 41.2 \pm 4.6 \mu \mathrm{m}$ and $15.6 \pm 1.7 \mu \mathrm{m}$ in control group, subgroups IIA, IIIA and IVA respectively. Mean epidermal thickness in subgroup IIA was highly significantly decreased $(\mathrm{P}<0.01)$ when compared to control group.
Subgroup IIIA expressed highly significant increase (P $<0.01)$ when compared to subgroup IIA while subgroup IVA represented non-significant increase $(\mathrm{P}>0.05)$ when compared to subgroup IIA. Mean epidermal thickness of subgroup IIB was zero $\mu \mathrm{m}$. This value showed progressive increase to reach $62.2 \pm 5.3 \mu \mathrm{m}$ and $99.2 \pm 4.8$ in subgroups IIIB \& IVB respectively, achieving a statistically highly significant increase $(\mathrm{P}<0.01)$ when compared to subgroup IIB and control group.

\section{Mean Area Percent of Collagen Fibers (Histogram 2):}

Mean area \% of collagen fibers of control group was $43.6 \pm 7.7$, this value decreased to $19.5 \pm 4.2$ in subgroup IIA \& $15.7 \pm 7.4$ in subgroup IIB representing a statistically highly significant decrease $(\mathrm{p}<0.01)$ when compared to control group. Mean area \% of collagen fibers of subgroups IIIA \& IVA was $39.5 \pm 8.0$ and $36.9 \pm 7.9$ respectively, expressing a highly significant increase $(p<0.01)$ when compared to subgroup IIA. In subgroups IIIB \& IVB, mean area $\%$ of collagen fibers was $37.2 \pm 4.7$ and $30.8 \pm 8.0$ respectively, expressing a highly significant increase $(p<$ 0.01) when compared to subgroup IIB.

\section{Mean Number of PCNA Immunopositive Cells (Histogram 3):}

The lowest value for mean number of PCNA immunopositive cells was recorded in subgroup IIA (3.0 \pm 0.8$)$ represented a statistically highly significant decrease $(\mathrm{p}<0.01)$ when compared to control group (10.1 \pm 2.4$)$. Mean number of PCNA immunopositive cells of subgroups IIIA \& IVA was $8.6 \pm 2.1$ and $6.4 \pm 1.5$ respectively, it was significantly higher when compared to subgroup IIA. Mean number of PCNA immunopositive cells was $16.4 \pm 2.3,12.6 \pm 3.3$ and $15.0 \pm 1.5$ in subgroup IIB, IIIB and IVB respectively. Value in subgroup IIIB recorded a significant decrease when compared to subgroup IIB, while subgroup IVB recorded a highly significant increase when compared with control group.

\section{Mean Number of CK19 Immunopositive Cells (Histogram 4):}

Mean number of immunopositive cells in subgroup IIA was $0.8 \pm 0.6$ reported a statistically highly significant decrease when compared to control group (2.2 \pm 0.7$)$. Mean number of CK19 immunopositive cells in subgroup IIIA was $2.0 \pm 0.6$ showed a statistically significant increase when compared to subgroup IIA. Meanwhile subgroup IVA reported a value of $(1.0 \pm 0.4)$ represented a statistically highly significant decrease when compared to control group. Mean number of CK19 immunopositive cells in subgroup IIB was $3.5 \pm 1.3$ represented a significant increase when compared to control group, Mean number of CK19 immunopositive cells in subgroup IIIB (1.8 \pm 0.4$)$ and IVB $(2.1 \pm 0.7)$ reported a significant decrease when compared with subgroup IIB. 


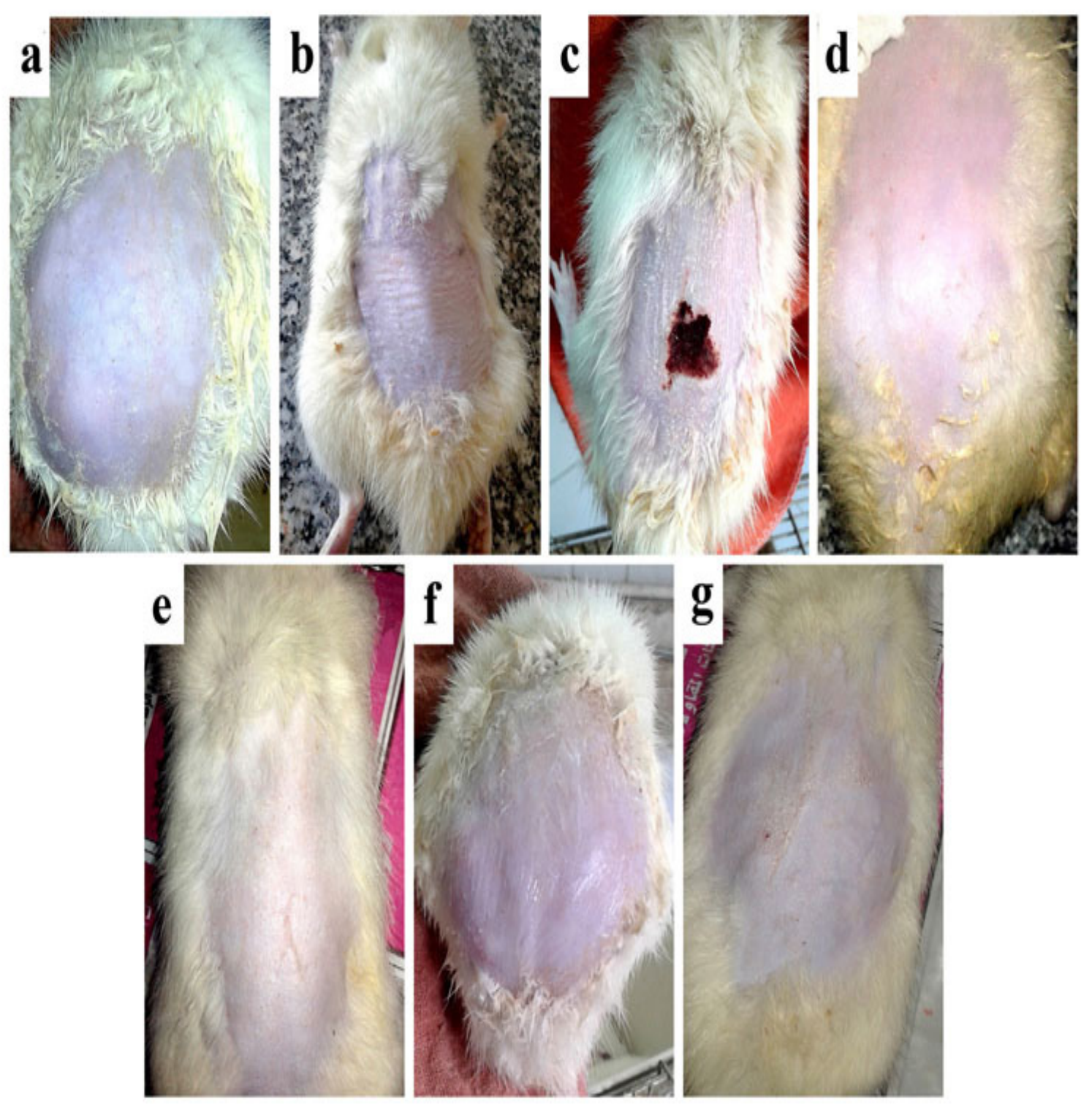

Plate 1: Photograph showing the skin of a rat from:

a) Control group; skin appear healthy and thick.

b) Subgroup IIA; skin is apparently thin and wrinkled.

c) Subgroup IIB; wound area is completely covered by scab.

d) Subgroup IIIA and f) subgroup IVA showing apparently healthy skin.

e) Subgroup IIIB and g) subgroup IVB showing complete healing of wound 

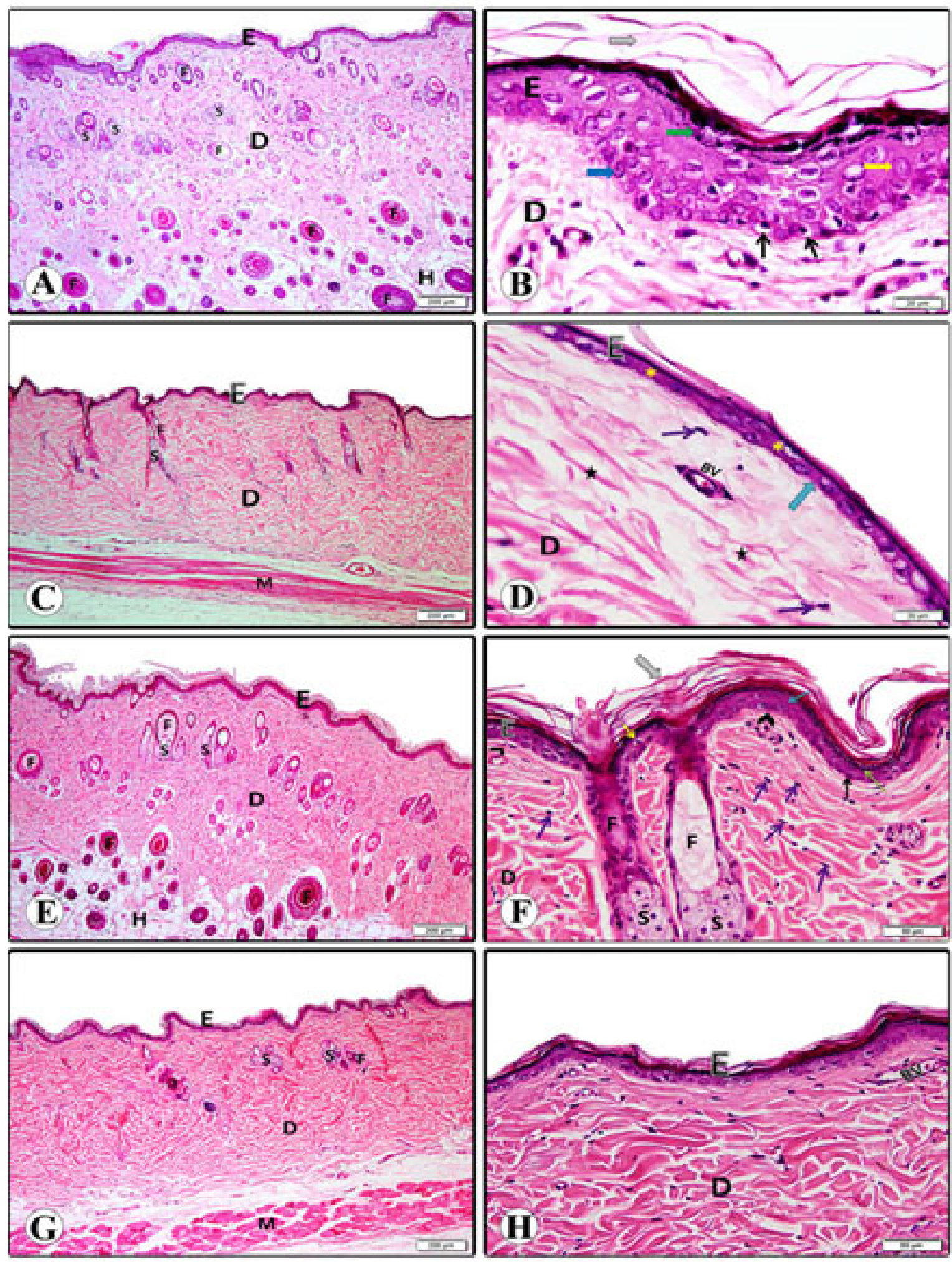

Plate 2: Photomicrograph of a section in rat skin from:

A\&B) control group showing epidermis (E) is formed of basal (blue arrow), prickle (yellow arrow), granular (green arrow) and horny layers (grey arrow) with Langerhans cells (white arrows) in intermediate layer. Dermis (D) consisted of densely packed collagen bundles with many fibroblasts. Many hair follicles (F) and sebaceous glands (S) are seen.

C\&D) subgroup IIA: showing thin epidermis with reduced size and number of keratinocytes, increased spaces in between their nuclei (yellow stars), dermis showing few fibroblasts (purple arrows) with separated collagen bundles (black stars) and scanty hair follicles and sebaceous glands.

E\&F) subgroup IIIA showing increased epidermal thickness with many hair follicles and sebaceous glands.

G\&H) subgroup IVA showing thin epidermis with few hair follicles and sebaceous glands, both subgroups showing an abundant fibroblasts with denser collagen bundles.

(H\&E: A,C,E \&G x40; B\&D x400; F\&H x200). 
Fawzy et. al.,
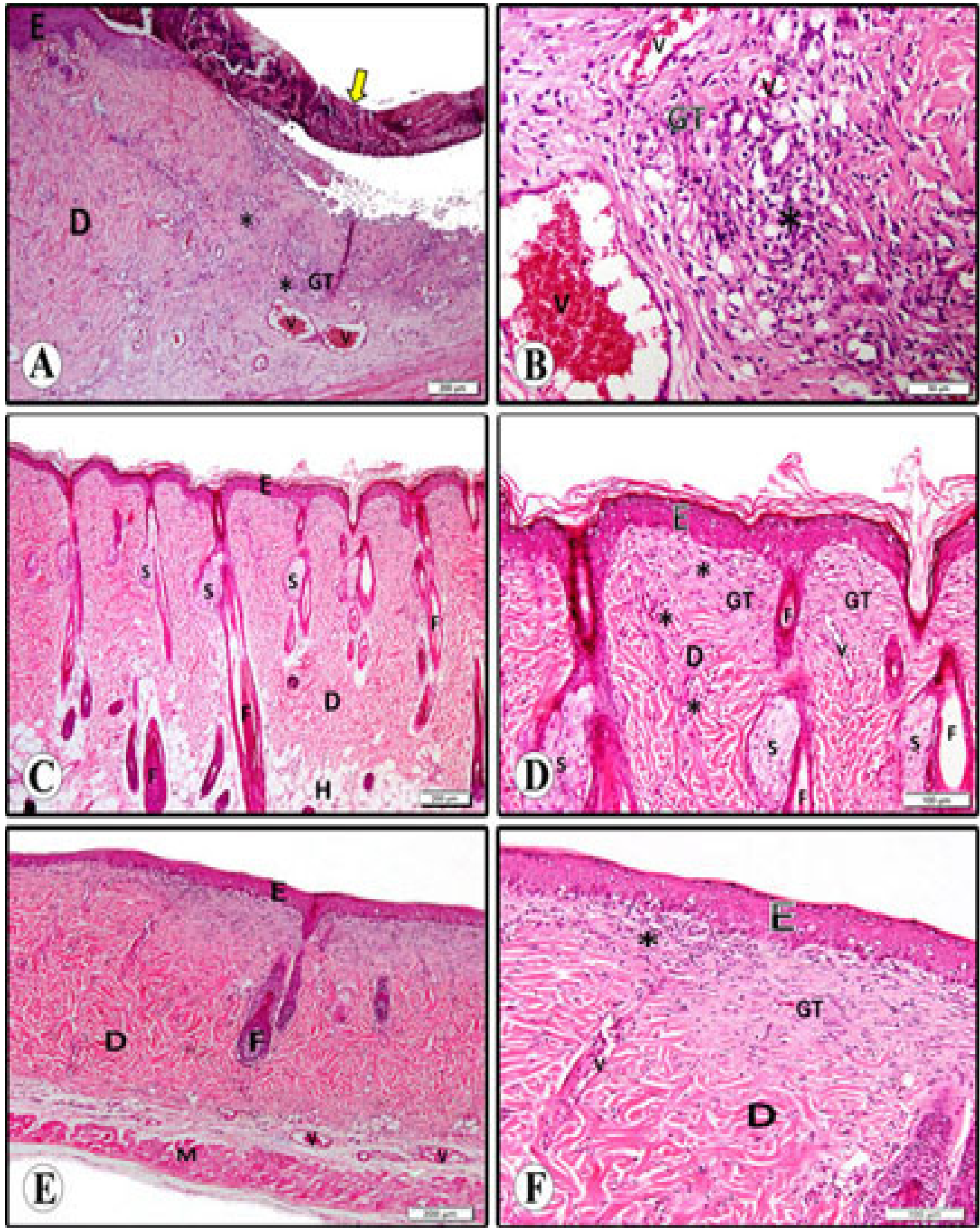

Plate 3: Photomicrograph of a section in rat skin from:

A\&B) subgroup IIB: showing wound surface covered by crust (yellow arrow), wound bed filled with massive inflammatory cell infiltrate (black star) with numerous congested blood vessels (V) (granulation tissue) (GT). Adjacent epidermis (E) is seen encroaching at edge of wound under crust.

C\&D) subgroup IIIB: wound area showing complete regeneration of epidermal, dermal layers and skin appendages. Note small area of granulation tissue (GT) with mild inflammatory cell infiltration (black star) and few dilated blood vessels (V).

E\&F) subgroup IVB: showing apparently thick epidermis covering the wound surface and wound bed filled by regenerated dermal components with wide area of granulation tissue (GT) and few hair follicles (F).

(H\&E: A,C\&E x40; B x200; D\&F x100) 

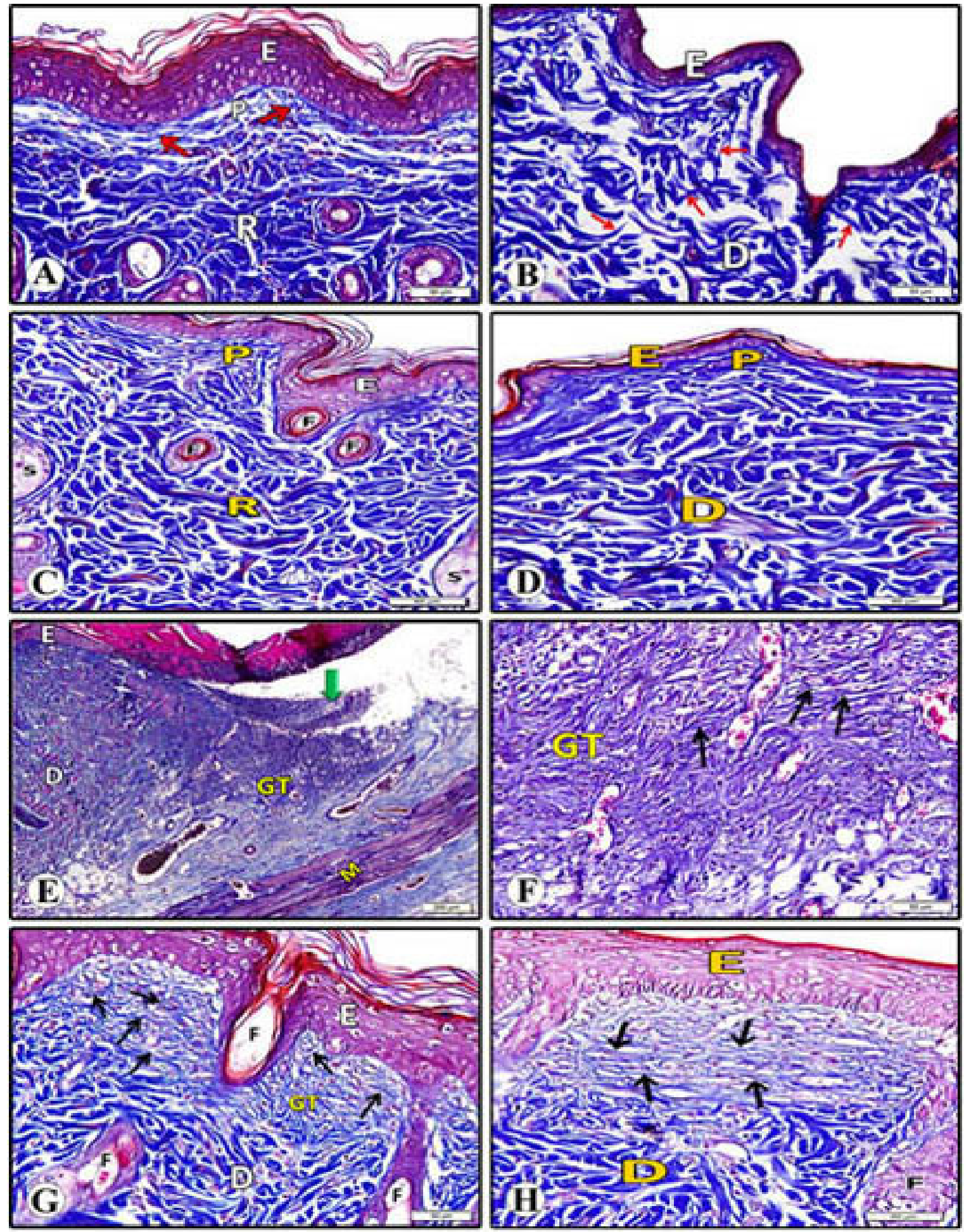

Plate 4: Photomicrograph of a section in rat skin from:

A) Control group showing fine collagen bundles (arrows) in papillary layer (P) and dense collagen bundles in reticular layer (R)

B) Subgroup IIA showing thin separated collagen fibers (red arrows).

C) Subgroup IIIA and D) subgroup IVA showing slight narrowing of papillary layer.

E\&F) subgroup IIB showing wound bed (green arrow) filled with thin collagen bundles (black arrows) in granulation tissue (GT) aligned in horizontal direction. Thick collagen bundles are present at wound edge in adjacent dermis (D).

G) Subgroup IIIB and $\mathbf{H}$ ) subgroup IVB showing thin collagen bundles at upper part of regenerated dermis while deep part filled with dense thick collagen bundles arranged in different directions. 

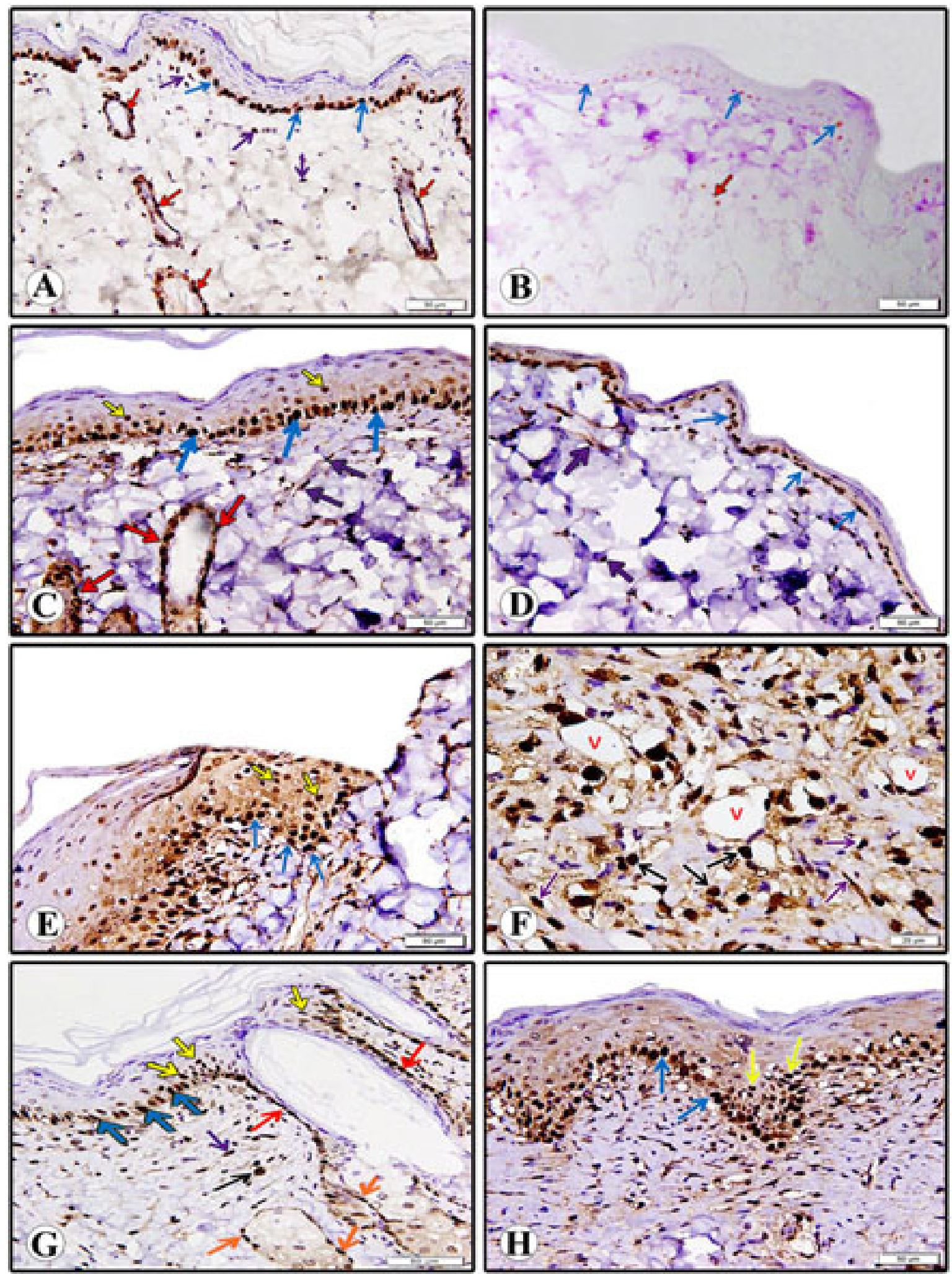

Plate 5: Photomicrograph of a section in rat skin from:

A) control group, C) subgroup IIIA, D) subgroup IVA, G) subgroup IIIB and $\mathbf{H}$ ) subgroup IVB showing moderate to dense immunoreactive cells in stratum basale (blue arrows), some cells of stratum spinosum (yellow arrows) and fibroblasts (purple arrows), moreover immunoreactivity is dense at cells of outer root sheath (ORS) of hair follicles (red arrows) in A, C \& G. Positive immunoreactivity is seen in mononuclear cells (black arrows) and basal cells of sebaceous glands (orang arrows) in $\mathrm{G}$.

B) subgroup IIA showing weak immunoreactivity in few cells of both stratum basale and ORS

E\&F) subgroup IIB showing dense widespread immunoreactive cells of strata basale and spinosum at wound margin as well as in mononuclear, fibroblastic and vascular endothelial (V) cells in regenerated granulation tissue. 

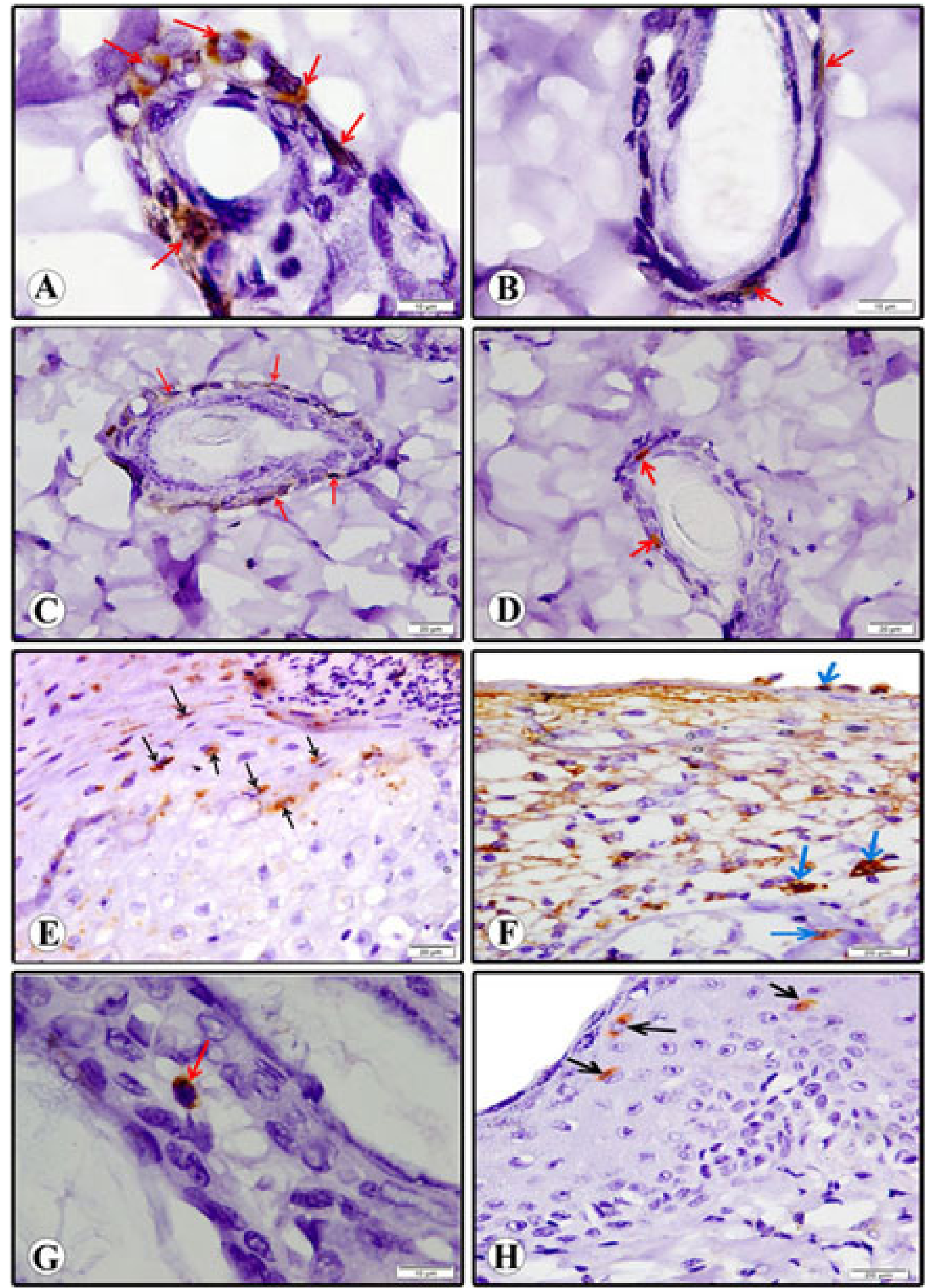

Plate 6: Photomicrograph of a section in rat skin from:

A) control group, C) subgroup IIIA , D) subgroup IVA and G) subgroup IIIB showing positive immunoreactive cells in ORS of hair follicles (red arrows). B) Subgroup IIA showing weak immunoreactivity in few cells of ORS.

E\&F) subgroup IIB showing immunoreactivity in epidermal cells at wound margin (black arrows), some cells with CK19 immunoreaction are seen scattered at wound bed (blue arrows).

H) Subgroup IVB showing positive immunoreactivity at some cells of regenerated epithelium. 
Histogram 1: Mean values of epidermal thickness (in micrometers) in control and experimental animal subgroups

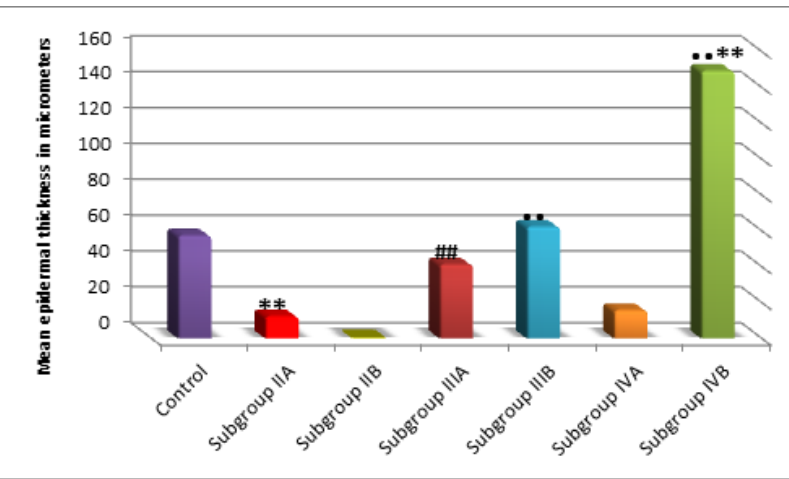

** Highly significantly different from value of control group at $P<0.01$

\#\# Highly significantly different from value of subgroup IIA at $P<0.01$.

$\bullet \bullet$ Highly significantly different from value of subgroup IIB at $P<0.01$.

Histogram 2: Mean values of area percent of collagen fibers in control and experimental animal subgroups.

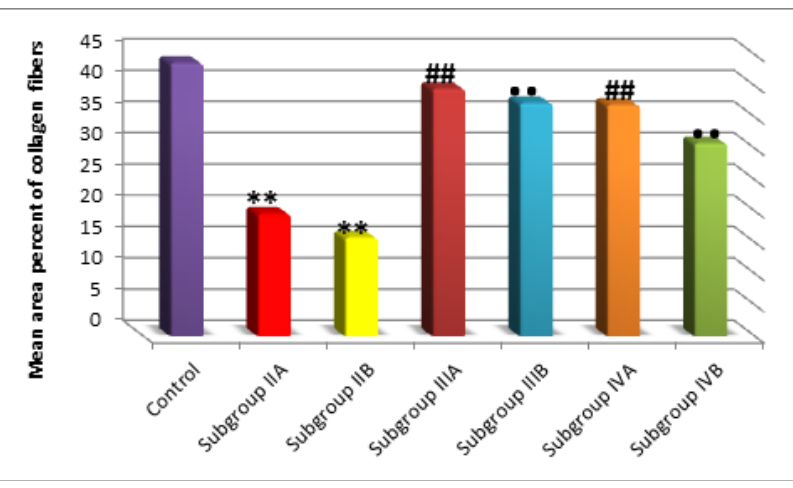

** Highly Significantly different from the value of control group at $P<0.01$. \#\# Highly Significantly different from the value of subgroup IIA at $P<0.01$.

$\bullet \bullet$ Highly Significantly different from the value of subgroup IIB at $P<0.01$.

Histogram 3: Mean values of number of PCNA immunopositive cells in the control and experimental animal subgroups.

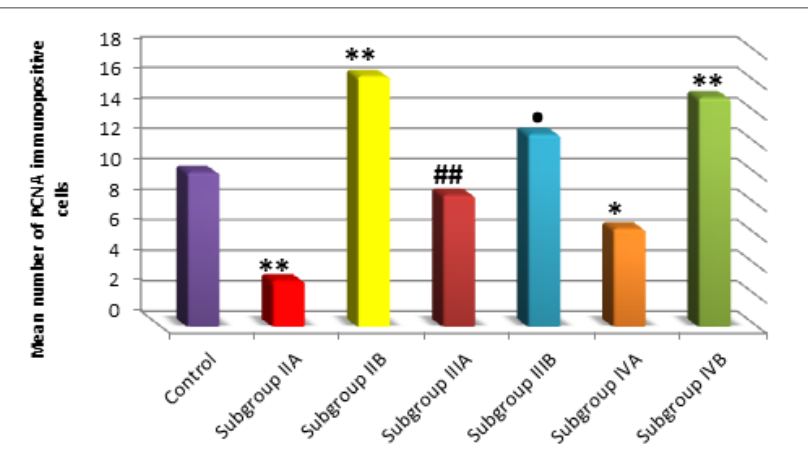

** Highly Significantly different from the value of control group at $P<0.01$

\#\# Highly Significantly different from the value of subgroup IIA at $P<0.01$.

* Significantly different from the value of subgroup IIA at $P<0.05$.

- Significantly different from the value of subgroup IIB at $P<0.05$.
Histogram 4: Mean values of number of CK19 immunopositive cells in control and experimental animal subgroups

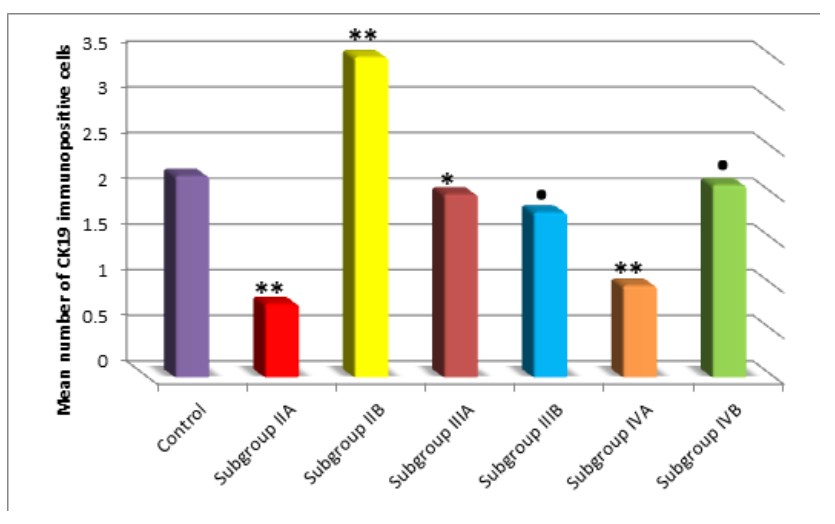

** Highly Significantly different from the value of control group at $P<0.01$.

* Significantly different from the value of subgroup IIA at $P<0.05$.

- Significantly different from the value of subgroup IIB at $P<0.05$.

\section{DISCUSSION}

In present study, the chosen clobetasol propionate is the most powerful type of steroid drugs, it was applied on skin for successive 15 days as it was previously deduced that prolonged usage of topical steroids are often accompanied by several cutaneous side effects such as atrophy, acne and exacerbation of skin infections ${ }^{[19]}$.

Gross examination of rat skin in subgroup IIA showed cutaneous thinning and wrinkling. Going with our results, studies on topical steroid detected the most relevant side effect is skin atrophy depending on its duration, chemical structure and potency. Atrophic skin was characterized by lost its thickness with increased fragility and decreased barrier function ${ }^{[3]}$.

Histological examination of H\&E stained sections of same subgroup showed thinning of epidermis as confirmed statistically, reduced number and size of keratinocytes with increased intercellular spaces. Few fibroblasts, widely separated collagen bundles, scanty hair follicles and few sebaceous glands were also seen at underlying dermis. Mean area percent of Masson's trichrome stained collagen fibers was statistically highly significant. Decreased cell proliferative rate via reduced their mitotic rates was confirmed by declined PCNA immunopositive cells.

It was explained that reduced keratinocyte size and accelerated maturation might be due to shorter epidermal cell life ${ }^{[20 \& 2]}$. On the other hand, different authors suggested that decreased size of keratinocytes might be due to reduced biosynthesis of their macromolecules ${ }^{[3]}$. However, it was claimed that reduction in epidermal cell size reflected a decreased metabolic activity of these cells ${ }^{[21]}$. It was reported that GC induce severe thinning of collagen fibers of dermis ${ }^{[22]}$. Deleterious effects of clobetasol propionate on dermis might be attributed to decreased proliferation of fibroblasts with production of ECM proteins ${ }^{[3]}$ and inhibition of collagen type $1 \& 3$ synthesis ${ }^{[19]}$. 
Localized weak PCNA immunoreactivity in few cells of both stratum basale and ORS of atrophied hair follicles was confirmed statistically and was previously reported as marked reduction of PCNA-positive cells in GC-treated epidermis $^{[23]}$. Also, weak CK19 immunoreactivity was confirmed statistically, it was in agreement with previous study which detected that after GC application keratinocyte proliferation and hair follicles was almost completely blocked and resulted in significant epidermal hypoplasia ${ }^{[24]}$.

Delayed wound healing in subgroup IIB with covered scab was still seen even by naked eye. H\&E stained sections showed crust with re-epithelialization failure. Wound bed observed absent skin appendages, massive inflammatory cells and numerous congested blood vessels with thin less collagen deposition as confirmed statistically. Epidermis adjacent to wound edge was thickened and extended over wound edge with increased number of Langerhans cells (LCs). It was suggested that this thickening caused by reactive acanthosis (proliferation of Malpighian cells) with reactive keratinocytes enlargement at wound edge ${ }^{[25]}$. Increased LCs number consistent with activation initiates a cascade of immune reactions in response to skin injury. Also, some authors previously observed LCs in wound edges between 0-48 hours, with significant reduction of their number 3 days post wounding ${ }^{[26]}$.

These findings were confirmed by marked increased PCNA immunopositive cell number. Also CK19+ve cells was observed at wound margin and bed. Similar findings were detected by previous authors who found that in a fullthickness wound, stem cell niche (bulge SCs) expressed CK15 that migrate into wound edges and center ${ }^{[27]}$.

Impaired wound healing by topical steroid showed that on seventh post wounding day, rats received corticosteroid were still in inflammatory phase ${ }^{[5]}$. It was explained that a corticosteroid application in early wound healing delayed appearance of fibroblasts, collagen deposition, capillaries regeneration and epithelial migration ${ }^{[28]}$. Decreased expression of TGF- $\beta$ which performed a vital role in collagen synthesis and turnover occurred by $\mathrm{GC}^{[29 \& 30]}$. Increased CK19+ve cells might be due to stimulation of bulge SCs by skin wound as agreed with other authors who postulated that bulge SCs play a vital role in epidermal regeneration after physical or chemical epidermal removal, superficial skin wound or burns ${ }^{[27 \& 31]}$.

Gross examination of subgroups IIIA and IIIB revealed healthy skin appearance with complete skin wound healing. Wound closure was previously documented to be improved in steroid-treated rats that received curcumin ${ }^{[32]}$. Among the numerous natural remedies, curcumin has gained considerable attention due to its profound worldwide use for medicinal and food purposes ${ }^{[33]}$.

In subgroup IIIA, improving effects of curcumin on skin were evident after its application for 12 days in form complete regeneration of epidermis and dermis with many hair follicles and sebaceous glands. Moreover underlying dermal layer of skin showed many fibroblasts and denser arrangement of collagen fibers as compared with subgroup IIA.

Dermal layer of subgroup IIIB showed small area of granulation tissue with mild inflammatory cell infiltration and few dilated blood vessels. Increased deposition of thick collagen bundles which was denser and better organized, as compared to that of subgroup IIB. In subgroups IIIA \& IIIB, statistically high significant increased mean area percent of dermal collagen fibers were confirmed previously in wounds treated with collagenase ointment and Acheflan cream $^{[34]}$.

In subgroups (IIIA \& B), widespread dense PCNA immunoreactivity as well as increased CK19 positive cell number as confirmed statistically after its initial drop in subgroup IIA. These observations suggested improving effect of curcumin on epidermis and adnexal structures via stimulated cell proliferation, bulge SCs migration and differentiation. It was previously deduced that a rise in PCNA expression in skin tissues of curcumin treated rats suffering from burn lesions proved beneficial effects of topical application of curcumin in acceleration of wound healing ${ }^{[13]}$. Additionally, it was demonstrated that curcumin reduced edema, leukocytic infiltration and accelerated wound healing in the nasal mucosa ${ }^{[35]}$. Also it was reported that contribution of CK15-positive bulge cells, as evidenced by their absence from interfollicular epidermis 20 days post-wounding ${ }^{[27]}$. It was proved that bulge SCs do not actively participate in epidermal homeostasis but contribute to wound repair ${ }^{[36]}$ and other authors confirmed a delayed re-epithelialization when incisional wound was done in mice skin with absent $\mathrm{HF}^{[37]}$.

Naked eye skin examination of subgroups IVA \& IVB revealed apparently healthy skin with complete wound closure, which was in accordance with the findings of other authors ${ }^{[6]}$. Microscopic findings revealed thin epidermal thickness in subgroup IVA that confirmed statistically as decreased CK19+ve cell number and localized PCNA immunoreactivity. On other hand, appeared thick epidermis covering wound surface in subgroup IVB was confirmed statistically as widespread PCNA immunoreactivity and decreased CK19+ve cell number. Delayed healed wounds in diabetic foot ulcers accompanied with hyperproliferative epidermal keratinocytes mainly appear in suprabasal layers and thick cornified layer ${ }^{[38]}$. It is also suggested that bulge SCs play an important role in wound healing process via migration to wound area and differentiation.

Both subgroups (IVA \& B) included scanty skin appendages and slight increased dermal cellularity. Also collagen fibers appeared regularly arranged and dense which confirmed statistically. These findings were explained in a previous research by the that topically applied aftamed exerted its beneficial effects on wound healing by stimulated collagen deposition and angiogenesis fact $^{[14]}$.

Based on explanation that through regulation of hyaluronan synthase -2 in fibroblasts and keratinocytes, GC 
decreased level of hyaluronic acid (HA) ${ }^{[39]}$. High molecular weight HA has important tissue healing properties, including induction of angiogenesis, promotion of cell migration and proliferation as well as immunosuppressive effects ${ }^{[40]}$. Also, previous authors concluded in their studies on skin wounds that HA facilitated re-epithelialization, led to formation of soft tissue with good elasticity and increased microvascular density ${ }^{[41 \& 42]}$. So aftamed gel as a product composed of high-molecular weight HA has the ability to recover GC- induced skin effects.

\section{CONCLUSION}

The current work demonstrated that frequent applica $\neg$ tion of topical steroids almost was accompanied by skin atrophy and delay wound healing process. The obtained findings detected that topical application of curcumin had more improving effect on skin and its abrasions rather than aftamed gel.

\section{REFERENCES}

1. Sulzberger MB and Witten VH: Effect of topically applied compound $\mathrm{F}$ in selected dermatoses. $\mathrm{J}$ Invest Dermatol; (1952) 19:101-102.

2. Lemos MC, Correr WR, da Silva de Avó LR, Germano CMR, Kurachi C, Polikarpov I and Melo DG: Fluorescence spectroscopy as a tool to detect and evaluate glucocorticoid-induced skin atrophy. Lasers Med Sci; (2012) 27:1059-1065.

3. Schoepe S, Schäcke H, May E and Asadullah K: Glucocorticoid therapy-induced skin atrophy. Exp Dermatol; (2006) 15(6):406-420.

4. Rosen DJ, Patel MK, Freeman $\mathrm{K}$ and Weiss PR: A primary protocol for the management of ear keloids: results of excision combined with intraoperative and postoperative steroid injections. Plast Reconstr Surg; (2007) 120:1395-1400.

5. Alberti LR, Vasconcellos L de S and Petroianu A: Influence of local or systemic corticosteroids on skin wound healing resistance. Acta Cirúrgica Brasileira; (2012) 27 (4): 295-299.

6. Al Bayaty F, Abdulla M, Abu Hassan MI and Masud M: Wound healing potential by hyaluronate gel in streptozotocin-induced diabetic rats. Sci Res Essays; (2010) 5(18): 2756-2760.

7. Panchatcharam M, Miriyala S, Gayathri VS and Suguna L: Curcumin improves wound healing by modulating collagen and decreasing reactive oxygen species. Mol Cell Biochem; (2006) 290(12):87-96

8. Qian JJ, Zhai XG, Niu MH, Zhou Q and Zhou YJ: Curcumin inhibits iron overload-induced hepatocytic apoptosis and nuclear factor- $\mathrm{BB}$ activity. Zhonghua Yi Xue Za Zhi; (2012) 92(28):1997-2001.
9. Yu L, Yi J, Ye G, Zheng Y, Song Z, Yang Y, Song Y, Wang $Z$ and Bao Q: Effects of curcumin on levels of nitric oxide synthase and AQP-4 in a rat model of hypoxia-ischemic brain damage. Brain Res; (2012) 26(1475):88-95.

10. Carvalho MFP, Pereira CSB, Fregnani JH and Ribeiro FAQ: Comparative histological study on wound healing on rat's skin treated with Mitomycin C or Clobetasol propionate. Acta Cir Bras; (2015) 30(9):593-597.

11. Lateef H, Abatan OI, Aslam MN, Stevens MJ and Varani J: Topical pretreatment of diabetic rats with all-trans retinoic acid improves healing of subsequently induced abrasion wounds. Diabetes; (2005) 54(3):855-861.

12. Warner RL, Bhagavathula N, Nerusu K, Hanosh A, McClintock SD, Naik MK, Johnson KJ, Ginsburg I and Varani J: MDI 301, a nonirritating retinoid, improves abrasion wound healing in damaged/ atrophic skin. Wound Repair Regen; (2008) 16(1):117-124.

13. Kulac M, Aktas C, Tulubas F, Uygur R, Kanter M, Erboga M, Ceber M, Topcu B and Ozen OA: The effects of topical treatment with curcumin on burn wound healing in rats. J Mol Histol; (2013) 44:83-90.

14. Al-Bayaty F and Abdulla MA: A Comparison of Wound Healing Rate Following Treatment with Aftamed and Chlorine Dioxide Gels in StreptozotocinInduced Diabetic Rats. Evid Based Complement Alternat Med; (2012) 2012 (468764): 1-8.

15. Ozmen J, Bobryshev Y, Lord R and Ashwell $\mathrm{KW}$ : Identification of dendritic cells in aortic atherosclerotic lesions in rats with diet-induced hypercholesterolaemia. Histol Histopathol; (2002) 17(1):223-237.

16. Kiernan JA: Histological and histochemical methods: theory and practice. 5th ed., Scoin publisher, United Kingdom, (2015) p.111- 162.

17. Bancroft JD and Gamble M: Connective tissue stains. In: Theory and practice of histological techniques, 6th ed., Bancroft JD and Gamble M (eds.), Elsevier Health Sciences, Churchill Livingstone, Edinburgh, London, Oxford, New York, Philadelphia, St Louis, Sydney and Toronto, (2008) p. 150.

18. Suvarna SK, Layton C and Bancroft JD: Bancroft's theory and practice of histological techniques, $7^{\text {th }}$ ed., Elsevier Health sciences, Churchill Livingstone, (2012) p.381-426 and 493-538.

19. Hengge UR, Ruzicka T, Schwartz RA and Cork MJ: Adverse effects of topical glucocorticosteroids. J Am Acad Dermatol; (2006) 54(1):1-15. 
20. Berth-Jones J: Topical therapy. In: Rooks Textbook of Dermatology, 8th ed., Burns T, Breathnach S, Cox N and Griffiths C (eds.), Blackwell Science Ltd, UK, (2010) p. 1-73.

21. Srinivas CR and Lakshmi C: Principles of topical therapy in dermatology. In: IADVL Textbook of Dermatology, 3rd ed., Valia RG and Valia AR (eds.), Bhalani Publishing House, Mumbai, India, (2008) p. 1591-1618.

22. Baida G, Bhalla P, Kirsanov K, Lesovaya E, Yakubovskaya M, Yuen K, Guo S, Lavker RM, Readhead B, Dudley JT and Budunova I: REDD1 functions at the crossroads between the therapeutic and adverse effects of topical glucocorticoids. EMBO Molecular Medicine; (2015) 7 (1): 42-58.

23. Man G, Mauro TM, Kim PL, Hupe M, Zhai Y, Sun R, Crumrine D, Cheung C, Nuno-Gonzalez A, Elias PM and Man MQ: Topical hesperidin prevents glucocorticoid-induced abnormalities in epidermal barrier function in murine skin. Exp Dermatol; (2014) 23(9): 645-651.

24. Chebotaev DV, Yemelyanov AY, Lavker RM and Budunova IV: Epithelial Cells in the Hair Follicle Bulge do not Contribute to Epidermal Regeneration after Glucocorticoid-Induced Cutaneous Atrophy. Journal of Investigative Dermatology; (2007) 127: 2749-2758.

25. Basiouny HS, Salama NM, Zeinab Mohamed El Maadawi ZM and Farag EA: Effect of Bone Marrow Derived Mesenchymal Stem Cells on Healing of Induced Full-Thickness Skin Wounds in Albino Rat. International Journal of Stem Cells; (2013) 6:12-25.

26. Stojadinovic O, Yin N, Lehmann J, Pastar I, Kirsner RS and Tomic-Canic M: Increased number of Langerhans cells in the epidermis of diabetic foot ulcers correlates with healing outcome. Immunol Res; (2013) 57(1-3):222-228.

27. Ito M, Liu Y and Yang Z: Stem cells in the hair follicle bulge contribute to wound healing but not to homeostasis of the epidermis. Nature Medicine; (2005) 11: 1351- 1354.

28. Bosanquet DC, Rangaraj A, Richards AJ, Riddell A, Saravolac VM and Harding KG: Topical steroids for chronic wounds displaying abnormal inflammation. Ann R Coll Surg Engl; (2013) 95: 291-296.

29. Gal P, Kilik R, Mokry M, Vidinsky B, Vasilenko T, Mozes S, Bobrov N, Tomori Z, Bober J and Lenhardt L: Simple method of open skin wound healing model in corticosteroid-treated and diabetic rats: standardization of semi-quantitative and quantitative histological assessments. Veterinarni Medicina; (2008) 53 (12): 652-659.
30. Uva L, Miguel D, Pinheiro C, Antunes J, Cruz D, Ferreira J and Filipe P: Mechanisms of Action of Topical Corticosteroids in Psoriasis. International Journal of Endocrinology; (2012) 2012: 561018.

31. Levy V, Lindon C, Harfe BD and Morgan BA: Distinct stem cell populations regenerate the follicle and interfollicular epidermis. Dev Cell; (2005) 9: 855-861

32. Bhagavathula $\mathrm{N}$, Warner RL, DaSilva $\mathrm{M}$, McClintock S, Barron A, Aslam MN, Johnson K and Varani J: A Combination of Curcumin and Ginger Extract Improves Abrasion Wound Healing in Corticosteroid Damaged Hairless Rat Skin. Wound Repair Regen; (2009) 17(3): 360-374.

33. Sarafian G, Afshar M, Mansouri P, Asgarpanah J, Raoufinejad K and Rajabi M : Topical Turmeric Microemulgel in the Management of Plaque Psoriasis; A Clinical Evaluation. Iran J Pharm Res; (2015) 14(3): 865-876.

34. Perini JA, Angeli-Gamba T, Alessandra-Perini J, Ferreira LC, Nasciutti LE and Machado DE: Topical application of Acheflan on rat skin injury accelerates wound healing: a histopathological, immunohistochemical and biochemical study. BMC Complement Altern Med; (2015) 15: 203.

35. Emiroglu G, Ozergin Coskun Z, Kalkan Y, Celebi Erdivanli O, Tumkaya L, Terzi S, Özgür A, Demirci $M$ and Dursun E : The Effects of Curcumin on Wound Healing in a Rat Model of Nasal Mucosal Trauma. Evid Based Complement Alternat Med; (2017) 2017:9452392.

36. Trempus CS, Morris RJ, Ehinger M, Elmore A, Bortner CD, Ito M, Cotsarelis G, Nijhof JGW, Peckham J, Flagler N, Kissling G, Humble MM, King LC, Adams LD, Desai D, Amin S and Tennant RW: CD34 Expression by Hair Follicle Stem Cells Is Required for Skin Tumor Development in Mice. Cancer Res; (2007) 67(9): 4173-4181.

37. Langton AK, Herrick SE and Headon DJ: An extended epidermal response heals cutaneous wounds in the absence of a hair follicle stem cell contribution. J Invest Dermatol; (2008) 128:13111318 .

38. Pastar I, Stojadinovic O, Yin NC, Ramirez H, Nusbaum AG, Sawaya A, Patel SB, Khalid L, Isseroff RR and Tomic-Canic M: Epithelialization in Wound Healing: A Comprehensive Review. Adv Wound Care (New Rochelle); (2013) 3(7): 445464.

39. Averbeck M, Gebhardt $\mathrm{C}$, Anderegg $\mathrm{U}$ and Simon JC: Suppression of hyaluronan synthase 2 expression reflects the atrophogenic potential of glucocorticoids. Exp Dermatol; (2010) 19(8):757759 . 
40. Silva EC, Omonte SV, Martins AG, de Castro HH, Gomes HE, Zenóbio ÉG, de Oliveira PA, Horta MC and Souza PE : Hyaluronic acid on collagen membranes: An experimental study in rats. Arch Oral Biol; (2017) 73:214-222.

41. Zhao JY, Chai JK, Song HF, Zhang J, Xu MH and Liang YD: Influence of hyaluronic acid on wound healing using composite porcine acellular dermal matrix grafts and autologous skin in rabbits. Int Wound J; (2013) 10:562-572.
42. Shimizu N, Ishida D, Yamamoto A, Kuroyanagi M and Kuroyanagi Y: Development of a functional wound dressing composed of hyaluronic acid spongy sheet containing bioactive components: evaluation of wound healing potential in animal tests. J Biomater Sci Polym Ed; (2014) 25:12781291. 
الملخص العربى

\title{
دراسه هستولوجيه على تأثير الكركم مقارنه بالأفتّاميد على ضمور الجلّا المستحدث بالجلوكوكورثيكويد و سحجات الجلد اللاحقه له فى ذكور الفئران
}

\author{
سهيز أحمد فوزي، نجوى عبد الوهاب أحمد،

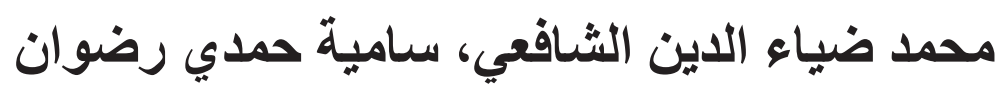

\section{قسم الهستولوجيا ـ كلية الطب - جامعة القاهرة}

الخلفيه: يعتبر الجلد هو أكبر عضو في الجسم من حيث المساحة السطحية والوزن و يعتبر ضمور الجلد هو واحد من أهم الآثار الجانبية للعلاج الموضعي بالجلوكوكورتيكويد. وقد صممت هذه الدر اسة لتقييم الأثار العلاجية المحتملة للكركم مقارنة بالأفتاميد جل) حمض الهيالورونيك( على ضمور الجلد المستحدث بالجلوكوكورتيكويد وسحجات الجلد اللاحقة

الأساليب: أجريت هذه الدراسة على إثنين وأربعين من ذكور الفئران البالغين. تم تقسيمهم الى اربعه مجموعات: مجمو عة 1 (المجموعة الضابطة) وتضم ستة فئر ان, مجموعة 2 (المجمو عة التى تعرضت للاسترويد), مجموعة 3 (المجموعة التى عولجت بالكركم) ومجموعة 4 (المجموعة التى عولجت بالأفتاميد جل). كل من المجموعات 2, 3 و 4 تم تقسيمهم الى المجموعات الفرعيه 2,3أو 4أ (المعرضه ل كلوبيتازول بروبيونات كريم) وتضم كل مجموعه ستة فئر ان و المجمو عات الفرعيه 2ب,3ب و 4ب (المعرضه لاحقا لسحج الجلد) وتضم كل مجموعه ستة فئران .تم

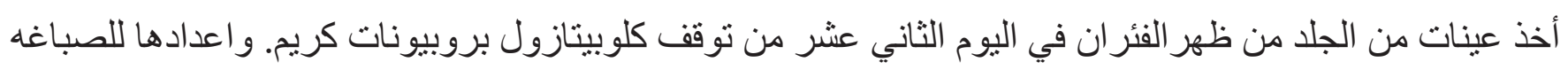

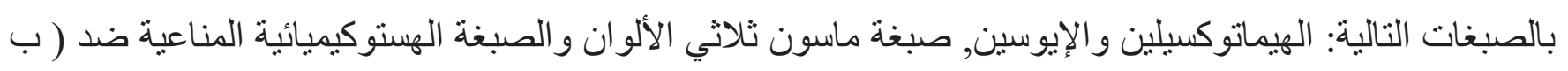
ك ن ا) و (س ك 19). وتم قياس سمك طبقة البشرة ، متوسط المساحة المئوية لألباف الكو لاجين ومتوسط عدد الخلايا المتفاعلة مع الصبغة الهستوكيميائية المناعية ( ب ك ن ا) و (س ك 19 ). النتائج: أظهرت المجموعة التى تعرضت للاسترويد نقص فى سمك طبقة البشرة والأدمة مع نقص كبير فى بصيلات الشعر و الغدد الدهنية بالاضافة الى تأخير

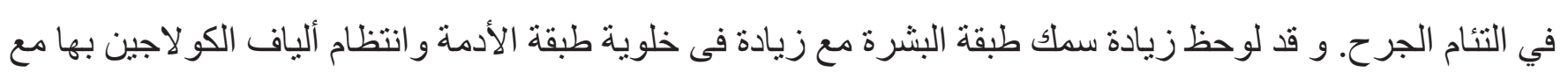
إرتفاع عدد الخلايا المناعيه الموجبه لل ( ب ك ن ا) و (س ك 19) وكان هذا التحسن اكثر وضوحا فى المجمو عة التى عولجت بالكركم. الاستنتاج: كان للعلاج الموضعى بالكركم تأثنير على ضمور الجلد و السحجات اللاحقه له اكثر تحسنا من الأفتاميد جل. 